617.735.2121; Fax: 617.735.2120; E-mail: ppandolf@bidmc.harvard.edu.

1. Guttman M, Rinn JL. Modular regulatory principles of large non-coding RNAs. Nature. 2012; 482(7385):339-346.

2. Salmena L, Poliseno L, Tay Y, Kats L, Pandolfi PP. A ceRNA hypothesis: the Rosetta Stone of a hidden RNA language? Cell. 2011;146(3):353-358.

3. Bratkovic T, Rogelj B. Biology and applications of small nucleolar RNAs. Cell Mol Life Sci. 2011; 68(23):3843-3851

4. Matera AG, Terns RM, Terns MP. Non-coding RNAs: lessons from the small nuclear and small nucleolar RNAs. Nat Rev Mol Cell Biol. 2007; 8(3):209-220.

5. Chu L, et al. Multiple myeloma-associated chromosomal translocation activates orphan snoRNA ACA11 to suppress oxidative stress. J Clin Invest. 2012;122(8):2793-2806.

6. Palumbo A, Anderson KN. Multiple myeloma. NEngl JMed. 2011;364(11):1046-1060.

7. Chesi M, Nardini E, Lim RS, Smith KD, Kuehl WM, Bergsagel PL. The $t(4 ; 14)$ translocation in myeloma dysregulates both FGFR3 and a novel gene, MMSET, resulting in IgH/MMSET hybrid transcripts. Blood. 1998;92(9):3025-3034.

8. Hoeppner MP, White S, Jeffares DC, Poole AM. Evolutionarily stable association of intronic snoRNAs and microRNAs with their host genes. Genome Biol Evol. 2009;1:420-428.

9. Bartel DP. MicroRNAs: target recognition and regulatory functions. Cell. 2009;136(2):215-233.

10. Williams GT, Farzaneh F. Are snoRNAs and snoRNA host genes new players in cancer? Nat Rev Cancer. 2012;12(2):84-88.

11. Dong XY, et al. Implication of snoRNA U50 in human breast cancer. J Genet Genomics. 2009;36(8):447-454.

12. Martens-Uzunova ES, et al. Diagnostic and prognostic signatures from the small non-coding RNA transcriptome in prostate cancer. Oncogene. 2012; 31(8):978-991.

13. Smith CM, Steitz JA. Classification of gas5 as a multi-small-nucleolar-RNA (snoRNA) host gene and a member of the 5'-terminal oligopyrimidine gene family reveals common features of snoRNA host genes. Mol Cell Biol. 1998;18(12):6897-6909.

14. Kino T, Hurt DE, Ichijo T, Nader N, Chrousos GP. Noncoding RNA gas5 is a growth arrest- and starvation-associated repressor of the glucocorticoid receptor. Sci Signal. 2010;3(107):ra8.

15. Lauring J, et al. The multiple myeloma associated MMSET gene contributes to cellular adhesion, clo- nogenic growth, and tumorigenicity. Blood. 2008; 111(2):856-864.

16. Michel CI, et al. Small nucleolar RNAs U32a, U33, and $U 35 a$ are critical mediators of metabolic stress. Cell Metab. 2011;14(1):33-44.

17. Ender C, et al. A human snoRNA with microRNAlike functions. Mol Cell. 2008;32(4):519-528.

18. Karreth FA, et al. In vivo identification of tumorsuppressive PTEN ceRNAs in an oncogenic BRAFinduced mouse model of melanoma. Cell. 2011; 147(2):382-395

19. Tay Y, et al. Coding-independent regulation of the tumor suppressor PTEN by competing endogenous mRNAs. Cell. 2011;147(2):344-357.

20. Cesana $\mathrm{M}$, et al. A long noncoding RNA controls muscle differentiation by functioning as a competing endogenous RNA. Cell. 2011;147(2):358-369.

21. Sumazin P, et al. An extensive microRNA-mediated network of RNA-RNA interactions regulates established oncogenic pathways in glioblastoma. Cell. 2011; 147(2):370-381.

22. Cazalla D, Yario T, Steitz JA. Down-regulation of a host microRNA by a Herpesvirus saimiri noncoding RNA. Science. 2010;328(5985):1563-1566.

23. Obad S, et al. Silencing of microRNA families by seed-targeting tiny LNAs. Nat Genet. 2011; 43(4):371-378.

\title{
Memory CD4+ T cells: beyond "helper" functions
}

\section{Kobporn Boonnak and Kanta Subbarao}

\author{
Laboratory of Infectious Diseases, National Institute of Allergy and Infectious Diseases (NIAID), NIH, Bethesda, Maryland, USA.
}

\begin{abstract}
In influenza virus infection, antibodies, memory $\mathrm{CD8}^{+} \mathrm{T}$ cells, and $\mathrm{CD}^{+}$ $T$ cells have all been shown to mediate immune protection, but how they operate and interact with one another to mediate efficient immune responses against virus infection is not well understood. In this issue of the JCI, McKinstry et al. have identified unique functions of memory $\mathrm{CD}^{+}$ $T$ cells beyond providing "help" for $\mathrm{B}$ cell and $\mathrm{CDB}^{+} \mathrm{T}$ cell responses during influenza virus infection.
\end{abstract}

Efficient control and clearance of viral infections requires coordinated interactions of several components of the immune system. Over the past 10 years, Susan Swain and colleagues have elucidated several functions of memory $\mathrm{CD} 4^{+} \mathrm{T}$ cells during influenza A virus (IAV) infection. They demonstrated the role of memory $\mathrm{CD}^{+}$ $\mathrm{T}$ cells in innate immune responses $(1,2)$, in the enhancement of $\mathrm{B}$ cell responses by follicular helper $\mathrm{T}\left(\mathrm{T}_{\mathrm{FH}}\right)$ cells via Signaling Lymphocyte Activation Molecule (SLAM)associated protein (SAP) expression (3), and in direct antiviral effects via a perforin-mediated cytotoxic mechanism $(4,5)$. In this issue of JCI, the Swain group, led by

Conflict of interest: The authors have declared that no conflict of interest exists.

Citation for this article: J Clin Invest. 2012; 122(8):2768-2770. doi:10.1172/JCI65208.
Kai McKinstry, systematically transferred memory $\mathrm{CD}^{+} \mathrm{T}$ cells into mice deficient in specific lymphocyte populations and elegantly dissected the mechanisms by which memory $\mathrm{CD} 4^{+} \mathrm{T}$ cells protect against IAV infection in mice (6). They report three new findings (Figure 1). First, the innate antiviral functions of memory $\mathrm{CD}^{+} \mathrm{T}$ cells are IFN- $\gamma$ dependent and independent of the pathogen recognition receptor (PRR) pathway (Figure 1A). Second, memory $\mathrm{CD} 4^{+} \mathrm{T}$ cells enhance $\mathrm{B}$ cell responses independently of $\mathrm{T}_{\mathrm{FH}}$ cells and germinal center formation (Figure 1B). Third, in addition to mediating effector functions via a perforin-dependent pathway (Figure 1C), memory $\mathrm{CD} 4^{+} \mathrm{T}$ cells use the same pathway to drive selection of escape mutants for a process that was known to occur in $\mathrm{CD}^{+}$ $\mathrm{T}$ cells (Figure 1D). These new findings are discussed below.

\section{Toward a better understanding of memory $\mathrm{CD4}^{+} \mathrm{T}$ cell immunity to influenza virus}

During primary influenza infection, $\mathrm{CD}^{+} \mathrm{T}$ cells provide help in promoting antibody production by $\mathrm{B}$ cells and are required for the generation of cytotoxic and memory $\mathrm{CD}^{+} \mathrm{T}$ cells (7). After the infection is resolved, the majority of effector $\mathrm{CD}^{+} \mathrm{T}$ cells undergo apoptosis, leaving behind a small population of memory $\mathrm{CD}^{+} \mathrm{T}$ cells, which respond more rapidly and effectively during reinfection. Several studies have suggested additional roles of memory $\mathrm{CD}^{+} \mathrm{T}$ cells during influenza reinfection, including enhancement of innate immune responses (1) as well as non-helper antiviral functions (8).

In the current study, McKinstry et al. demonstrate the role of memory $\mathrm{CD}^{+}$ $\mathrm{T}$ cells in immune protection from IAV infection. Memory $\mathrm{CD} 4^{+} \mathrm{T}$ cells protect mice that lack $\mathrm{T}$ or $\mathrm{B}$ cells, though $\mathrm{CD}^{+}$ $T$ cells are needed between days 6 and 10 after infection for viral clearance in B cell-deficient mice $(6,9)$. McKinstry et al. demonstrated that the protection conferred by memory $\mathrm{CD} 4^{+} \mathrm{T}$ cells in mice that lack both $\mathrm{T}$ and $\mathrm{B}$ cells is incomplete; 
A

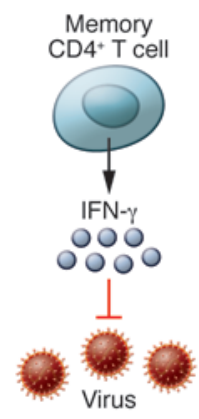

B

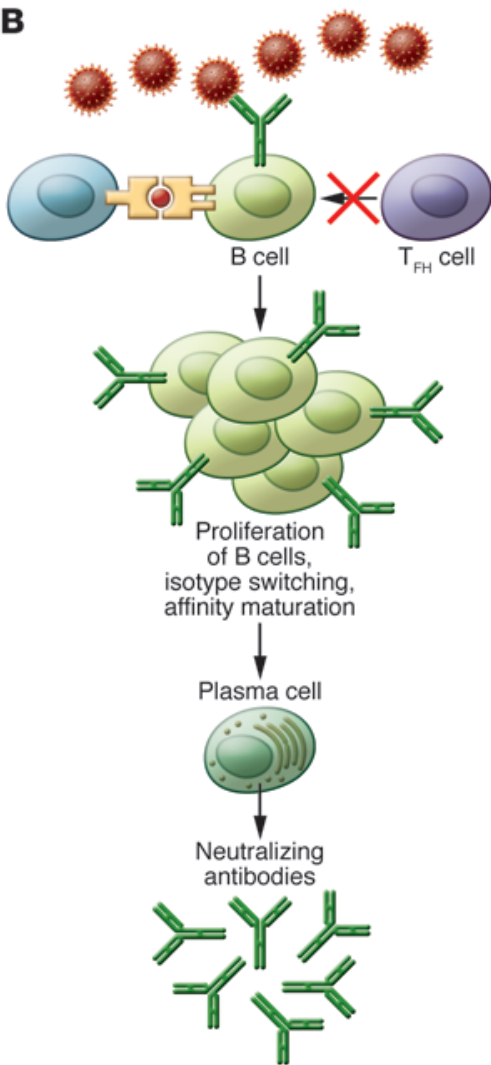

mice can be protected against low-dose viral challenge but not against high-dose challenge. Memory $\mathrm{CD}^{+} \mathrm{T}$ cells mediated protection against low-dose influenza infection via IFN- $\gamma$ production independently of other lymphocytes. The authors also found that to clear infection following a high dose of challenge virus, memory $\mathrm{CD}^{+} \mathrm{T}$ cells interacted with naive $\mathrm{B}$ cells and $\mathrm{CD} 8^{+} \mathrm{T}$ cells. The reduction in morbidity and mortality in the recipient mice was convincing, but the reduction in viral titers (expressed as polymerase [PA] gene copies) was very modest, though statistically significant (6). A relatively small change in pulmonary virus titer can be associated with remarkable dif-
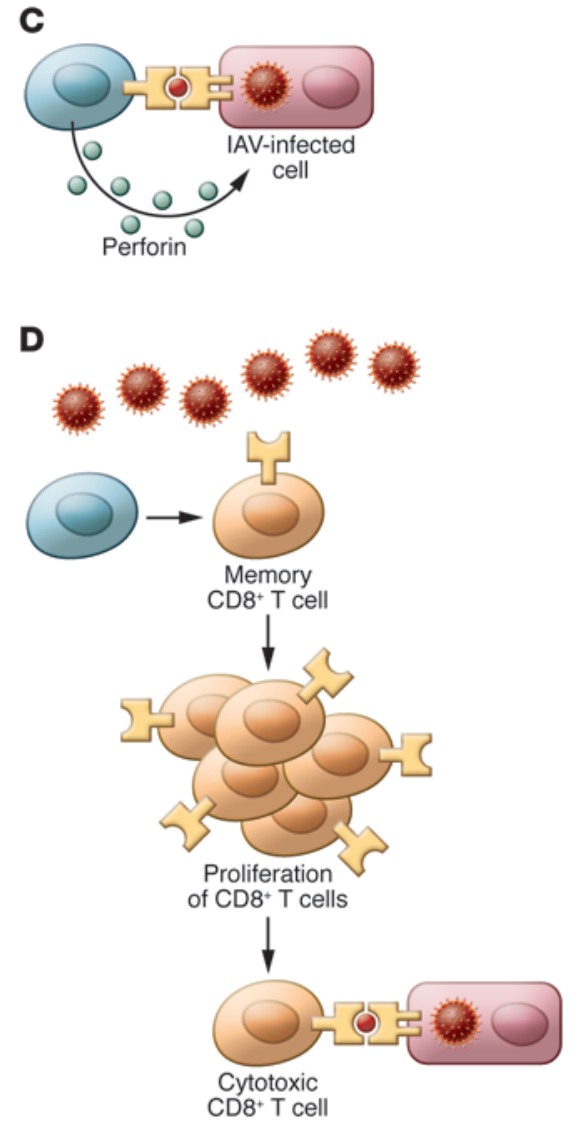

ferences in mortality in IAV infection in mice (10). In agreement with this study, preexisting memory $\mathrm{CD}^{+} \mathrm{T}$ cells have also been shown to correlate with disease protection against influenza challenge in humans (11-13).

\section{Direct role of memory $\mathrm{CD}^{+} \mathrm{T}$ cells in virus infection}

Although the most well-characterized function of memory $\mathrm{CD}^{+}{ }^{+} \mathrm{T}$ cells during viral infection is the maintenance of $\mathrm{B}$ cell and $\mathrm{CD}^{+} \mathrm{T}$ cell responses, several other roles of memory $\mathrm{CD} 4^{+} \mathrm{T}$ cells have been elucidated in IAV infection (14). Recent studies have shown that memory $\mathrm{CD}^{+}$ $\mathrm{T}$ cells, but not naive $\mathrm{CD} 4^{+} \mathrm{T}$ cells, enhance

\section{Figure 1}

Memory $T$ cell functions demonstrated during IAV infection. (A) Memory CD4+ $\mathrm{T}$ cells can clear low-dose influenza virus challenge independently of other lymphocytes by production of IFN- $\gamma$ via a PRR-independent pathway. (B-D) Memory CD4+ T cells act through multiple pathways to mediate protection against high-dose influenza virus challenge. Memory $\mathrm{CD}^{+} \mathrm{T}$ cells enhance antibody production by $B$ cells independently of $T_{F H}$ cells and germinal center formation (B), can select for influenza virus escape mutants through perforin-dependent cytotoxicity (C), and enhance $\mathrm{CD}^{+} \mathrm{T}$ cell responses (D). 
to as $\mathrm{T}_{\mathrm{FH}}$ cells. Following viral infection, $\mathrm{T}_{\mathrm{FH}}$ cells express SAP to direct the formation of germinal centers (16), where they promote the formation of memory $B$ cells and long-lived antibody-producing plasma cells. Memory $\mathrm{CD}^{+} \mathrm{T}$ cells are superior to naive $T$ cells in providing help to B cells: they promote earlier B cell proliferation, higher antibody levels, and earlier antibody class switching (17-19). Interestingly, McKinstry et al. show that, unlike naive $\mathrm{CD}^{+} \mathrm{T}$ cells, enhancement of $\mathrm{B}$ cell responses by memory $\mathrm{CD}^{+}$ $\mathrm{T}$ cells is not dependent on a $\mathrm{T}_{\mathrm{FH}}$-associated pathway.

Priming of $\mathrm{CD}^{+} \mathrm{T}$ cells by memory $\mathrm{CD}^{+} \mathrm{T}$ cells during IAV infection has been studied extensively (20-22), but the role of memory $\mathrm{CD}^{+} \mathrm{T}$ cells as cytotoxic effectors is less certain. This group has shown previously that memory $\mathrm{CD}^{+} \mathrm{T}$ cells mediate cytotoxicity by a perforin-dependent mechanism (4). Here, McKinstry et al. extended these findings by showing that memory $\mathrm{CD}^{+} \mathrm{T}$ cells select for influenza escape mutants and that this selection requires perforin. This mechanism is similar to that by which $\mathrm{CD}^{+}$ $\mathrm{T}$ cells select for escape variants (23).

\section{Questions and future challenges}

While the work by McKinstry et al. provides novel insights into cellular mechanisms by which memory $\mathrm{CD}^{+} \mathrm{T}$ cells contribute to immune protection against influenza, several questions remain. Areas that warrant further study include the PRR-independent protection elicited by memory $\mathrm{CD}^{+} \mathrm{T}$ cells via production of IFN- $\gamma$ in the absence of other lymphocytes and the synergy of memory $\mathrm{CD}^{+}$ $\mathrm{T}$ cells with $\mathrm{B}$ cells independent of $\mathrm{T}_{\mathrm{FH}}$ cells. Interestingly, Th17 cells also provided protection in this study, but their function was not well characterized. The precise role of Th17 in this complex network should be explored further. Although the authors discuss the role of memory $\mathrm{CD}^{+}$ $\mathrm{T}$ cells in heterosubtypic immunity (24), the experiments in the current study only evaluated protection from homologous viral challenge. Further study of the role of memory CD4 $4^{+} \mathrm{T}$ cells in heterosubtypic immunity is needed. The authors close with the suggestion that vaccines that elicit memory $\mathrm{CD}^{+} \mathrm{T}$ cell responses in addition to antibodies may offer universal protection against seasonal and pandemic influenza viruses. An exploration of approaches to achieve this result, e.g., by administration of influenza vaccines with oil-in-water adjuvants (25), would be of interest. Last but not least, while it is clear that such reductionist approaches are of great value in dissecting the pathways, it is not clear how translatable the findings will be from mice to humans.

\section{Acknowledgments}

The authors are supported by the Intramural Research Program of NIAID, NIH.

Address correspondence to: Kanta Subbarao, Emerging Respiratory Viruses Section, Laboratory of Infectious Diseases, NIAID, NIH, Bldg. 33, Room 3E13C.1, 33 North Drive, MSC 3203, Bethesda, Maryland 20892-3203, USA. Phone: 301.451.3839; Fax: 301.480.4749; E-mail: KSUBBARAO@niaid.nih.gov.

1. Strutt TM, et al. Memory CD4+ T cells induce innate responses independently of pathogen. Nat Med. 2010;16(5):558-564.

2. Strutt TM, McKinstry KK, Swain SL. Control of innate immunity by memory CD4 T cells. Adv Exp Med Biol. 2011;780:57-68.

3. Kamperschroer C, Swain SL, Grussenmeyer T, Lefkovits I. SAP deficiency results in a striking alteration of the protein profile in activated CD4 T cells. J Proteome Res. 2006;5(7):1785-1791.

4. Brown DM, Dilzer AM, Meents DL, Swain SL. CD4 $\mathrm{T}$ cell-mediated protection from lethal influenza: perforin and antibody-mediated mechanisms give a one-two punch. J Immunol. 2006;177(5):2888-2898.

5. McKinstry KK, et al. IL-10 deficiency unleashes an influenza-specific Th17 response and enhances survival against high-dose challenge. J Immunol. 2009;182(12):7353-7363.

6. McKinstry KK, et al. Memory CD4 ${ }^{+} \mathrm{T}$ cells protect against influenza through multiple synergizing mechanisms. J Clin Invest. 2012;122(8):2847-2856.

7. Topham DJ, Doherty PC. Clearance of an influenza A virus by CD4+ T cells is inefficient in the absence of B cells. J Virol. 1998;72(1):882-885.

8. Teijaro JR, Verhoeven D, Page CA, Turner D, Farber DL. Memory CD4 T cells direct protective responses to influenza virus in the lungs through helper-independent mechanisms. J Virol.
2010;84(18):9217-9226.

9. Miao H, et al. Quantifying the early immune response and adaptive immune response kinetics in mice infected with influenza A virus.J Virol. 2010;84(13):6687-6698

10. Epstein SL, et al. Mechanisms of heterosubtypic immunity to lethal influenza A virus infection in fully immunocompetent, T cell-depleted, beta2microglobulin-deficient, and J chain-deficient mice. J Immunol. 1997;158(3):1222-1230.

11. Lee LY, et al. Memory T cells established by seasonal human influenza A infection cross-react with avian influenza A (H5N1) in healthy individuals. $J$ Clin Invest. 2008;118(10):3478-3490.

12. Wilkinson TM, et al. Preexisting influenza-specific $\mathrm{CD} 4+\mathrm{T}$ cells correlate with disease protection against influenza challenge in humans. Nat Med. 2012;18(2):274-280

13. Schmidt T, et al. CD4(+) T-cell immunity after pandemic influenza vaccination cross-reacts with seasonal antigens and functionally differs from active influenza infection [published online ahead of print May 14, 2012]. Eur Immunol. doi:10.1002/ eji.201242393.

14. Swain SL, McKinstry KK, Strutt TM. Expanding roles for CD4(+) T cells in immunity to viruses. Nat Rev Immunol. 2011;12(2):136-148.

15. Min JY, Li S, Sen GC, Krug RM. A site on the influenza A virus NS1 protein mediates both inhibition of PKR activation and temporal regulation of viral RNA synthesis. Virology. 2007;363(1):236-243.

16. Crotty S, Kersh EN, Cannons J, Schwartzberg PL, Ahmed R. SAP is required for generating long-term humoral immunity. Nature. 2003; 421(6920):282-287.

17. MacLeod MK, David A, McKee AS, Crawford F, Kappler JW, Marrack P. Memory CD4 T cells that express CXCR5 provide accelerated help to B cells. JImmunol. 2011;186(5):2889-2896.

18. Bradley LM, Croft M, Swain SL. T-cell memory: new perspectives. Immunol Today. 1993; 14(5):197-199.

19. Croft M, Swain SL. Recently activated naive CD4 $\mathrm{T}$ cells can help resting B cells, and can produce sufficient autocrine IL-4 to drive differentiation to secretion of T helper 2-type cytokines. J Immunol. 1995;154(9):4269-4282.

20. Topham DJ, Tripp RA, Doherty PC. CD8+ T cells clear influenza virus by perforin or Fas-dependent processes. J Immunol. 1997;159(11):5197-5200.

21. Kalams SA, Walker BD. The critical need for CD4 help in maintaining effective cytotoxic $\mathrm{T}$ lymphocyte responses. J Exp Med. 1998;188(12):2199-2204.

22. Bevan MJ. Helping the CD8(+) T-cell response. Nat Rev Immunol. 2004;4(8):595-602.

23. Price GE, Huang L, Ou R, Zhang M, Moskophidis D. Perforin and Fas cytolytic pathways coordinately shape the selection and diversity of CD8+T-cell escape variants of influenza virus. $J$ Virol. 2005;79(13):8545-8559.

24. McKinstry KK, Strutt TM, Swain SL. Hallmarks of CD4 T cell immunity against influenza. J Intern Med. 2011;269(5):507-518

25. Galli G, et al. Adjuvanted H5N1 vaccine induces early CD4+ T cell response that predicts long-term persistence of protective antibody levels. Proc Natl Acad Sci U S A. 2009;106(10):3877-3882. 